University of Nebraska - Lincoln

DigitalCommons@University of Nebraska - Lincoln

USDA National Wildlife Research Center - Staff Publications
U.S. Department of Agriculture: Animal and Plant Health Inspection Service

$12-2010$

\title{
Activity Patterns of Wild Boars (Sus Scrofa) in Southern Texas
}

Tyler A. Campbell

National Wildlife Research Center, tcampbell@eastfoundation.net

David B. Long

Texas A\&M University-Kingsville

Follow this and additional works at: https://digitalcommons.unl.edu/icwdm_usdanwrc

Campbell, Tyler A. and Long, David B., "Activity Patterns of Wild Boars (Sus Scrofa) in Southern Texas" (2010). USDA National Wildlife Research Center - Staff Publications. 1260.

https://digitalcommons.unl.edu/icwdm_usdanwrc/1260

This Article is brought to you for free and open access by the U.S. Department of Agriculture: Animal and Plant Health Inspection Service at DigitalCommons@University of Nebraska - Lincoln. It has been accepted for inclusion in USDA National Wildlife Research Center - Staff Publications by an authorized administrator of DigitalCommons@University of Nebraska - Lincoln. 


\title{
NOTES
}

\section{ACTIVITY PATTERNS OF WILD BOARS (SUS SCROFA) IN SOUTHERN TEXAS}

\author{
Tyler A. Campbell* and David B. Long
}

\author{
United States Department of Agriculture, Animal and Plant Health Inspection Service, Wildlife Services, National \\ Wildlife Research Center, Texas AEM University-Kingsville, Kingsville, TX 78363 \\ *Correspondent: tyler.a.campbell@aphis.usda.gov
}

\begin{abstract}
Wild boars (Sus scrofa) are increasing in abundance and geographic distribution throughout North America. Our objectives were to determine daily and hourly activity patterns. We placed global-positioning-system collars on 25 wild boars from two sites in southern Texas. Wild boars at both sites displayed highly nocturnal activity patterns, and during the dormant and early growing season, activity increased with rising temperatures.

RESUMEN-Los jabalís (Sus scrofa) están incrementando su abundancia y distribución geográfica en toda Norteamérica. Nuestros objetivos fueron determinar los patrones de actividad por día y por hora. Colocamos collares con sistemas de posicionamiento global en 25 jabalís en dos sitios al sur de Texas. Jabalís en ambos sitios mostraron patrones de alta actividad nocturna, y durante la temporada de inactividad y crecimiento temprano, la actividad se incrementó con el aumento de la temperatura.
\end{abstract}

Free-ranging Sus scrofa, also known as wild boars (Wilson and Reeder, 2005), are increasing in abundance and geographic distribution throughout North America; established populations occur in the southwestern states of Arizona, California, Colorado, Kansas, Nevada, New Mexico, Oklahoma, and Texas (National Feral Swine Mapping System, http://feralswinemap.org). Information on their natural history, such as daily and seasonal activity patterns, is not available from much of this region and there is evidence that these patterns may vary by region. For example, in Australia, wild boars primarily are nocturnal (Saunders and Kay, 1991; Caley, 1997) and, in Tennessee and Texas, they primarily are crepuscular (Singer et al., 1981; Ilse and Hellgren, 1995). However, in South Carolina, wild boars shifted periods of activity from primarily diurnal during autumn, winter, and spring to primarily nocturnal during summer (Kurz and Marchinton, 1972). Plasticity in activity patterns has been noted in populations of wild boars in Italy (Boitani et al., 1994).

Limited evidence suggests that activity patterns of wild boars may be influenced by temperature in parts of eastern and southern Texas (Wyckoff et al., 2006). However, this relationship has not been demonstrated. Our objectives were to determine daily and hourly activity patterns and to evaluate the hypothesis that temperature influences activity of wild boars in southern Texas.

Our study was conducted in mixed-shrub rangelands in Kleberg and San Patricio counties, Texas. Our study site in Kleberg County was ca. 3,700 ha, it was on the Laureles Division of the King Ranch $\left(27^{\circ} 29^{\prime} \mathrm{N}, 97^{\circ} 37^{\prime} \mathrm{W}\right)$, and it received an average of $67 \mathrm{~cm}$ of rainfall annually. Our study site in San Patricio County was ca. 3,100 ha, it was on the Rob and Bessie Welder Wildlife Foundation $\left(28^{\circ} 06^{\prime} \mathrm{N}, 97^{\circ} 22^{\prime} \mathrm{W}\right)$, and it received an average of $79 \mathrm{~cm}$ of rainfall annually.

We trapped wild boars in Kleberg County during January 2008 and in San Patricio County during May 2008 using box traps. We restrained, determined sex, and placed ear-tags in all wild boars captured. We placed global-positioningsystem (GPS) collars (GPS 3300S, Lotek Wireless, Inc., Newmarket, Ontario, Canada) on animals $\geq 82 \mathrm{~kg}$. Our procedures were approved by the National Wildlife Research Center Institutional Animal Care and Use Committee (QA-1528).

We placed collars on wild boars for $\leq 15$ weeks and programmed collars to store locations at 


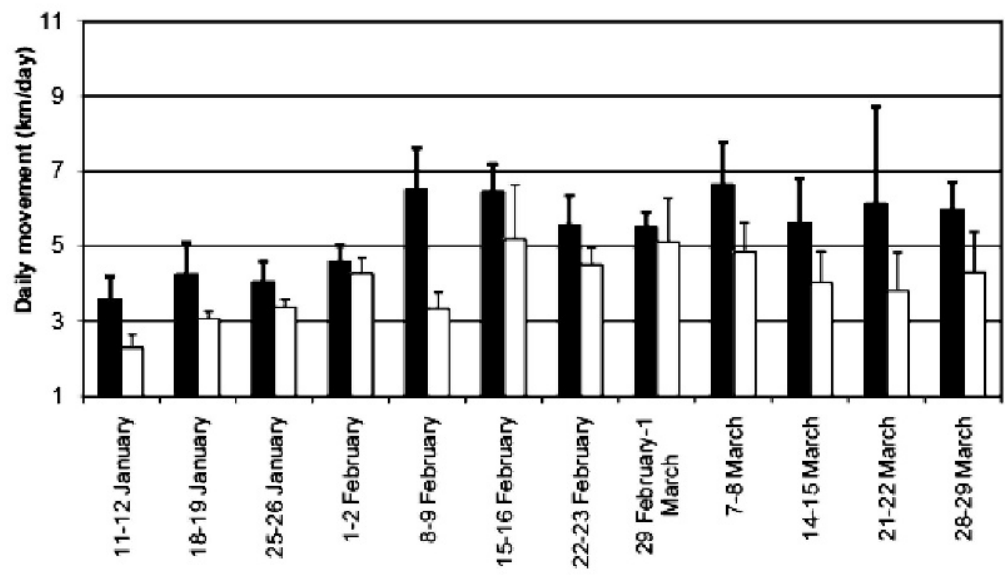

b

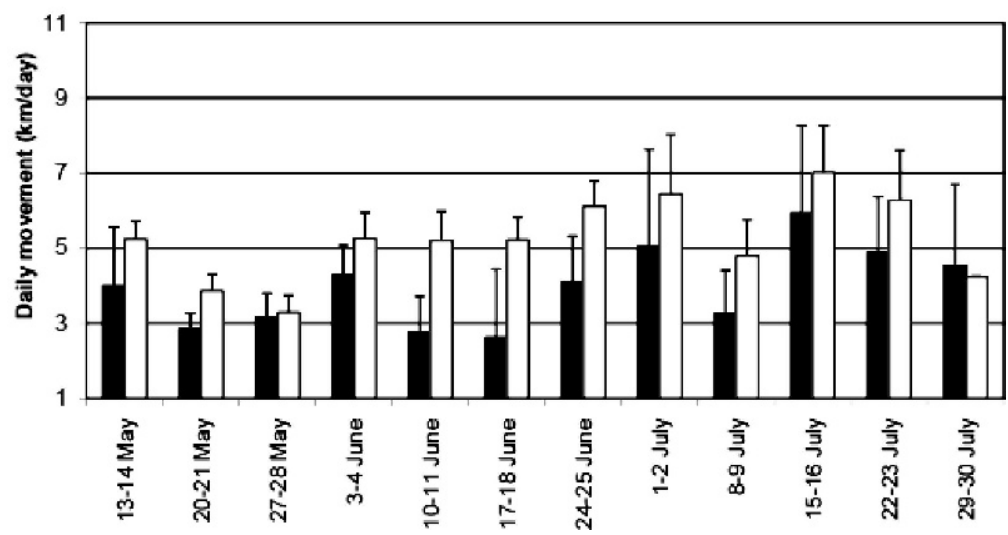

FIG. 1-Average $( \pm S E)$ daily movement (km/day) of male (closed bars) and female (open bars) wild boars (Sus scrofa) in (a) Kleberg and (b) San Patricio counties, Texas, 2008.

15-min intervals on 2 consecutive days during each week. We recovered collars by a radiocontrolled drop-off device in mid-April 2008 in Kleberg County and mid-August 2008 in San Patricio County. We overlaid data onto coverage maps of the study areas using ARCVIEW (Environmental Systems Research Institute, 1999). We recorded high and low temperatures daily from study sites during the time that collars were deployed. We generated a daily temperature index by calculating the mean of the daily high and low temperatures.

As a conservative measure of activity, we determined rates of movement from sequential locations of wild boars. We used the Animal Movement Extension of ARCVIEW to calculate distance between sequential locations. We calculated mean distance moved per hour. We report mean daily movement $(\mathrm{km} /$ day $)$ and mean hourly movement $(\mathrm{m} / \mathrm{h})$ by sex for study sites. We performed linear regression (PROC REG; SAS Institute, Inc., Cary, North Carolina) with index of mean daily temperature as an independent variable and mean daily distance moved per hour as a dependent variable by study site.

We trapped and ear-tagged 76 wild boars in Kleberg County and 67 in San Patricio County. We placed collars on nine males and four females in Kleberg County and five males and seven females in San Patricio. We downloaded 24,065 GPS locations from collars in Kleberg County and 16,041 locations from collars in San Patricio County. In Kleberg County, males tended to move greater distances per day than females; whereas in San Patricio County, females tended to move greater distances per day than males (Fig. 1). 

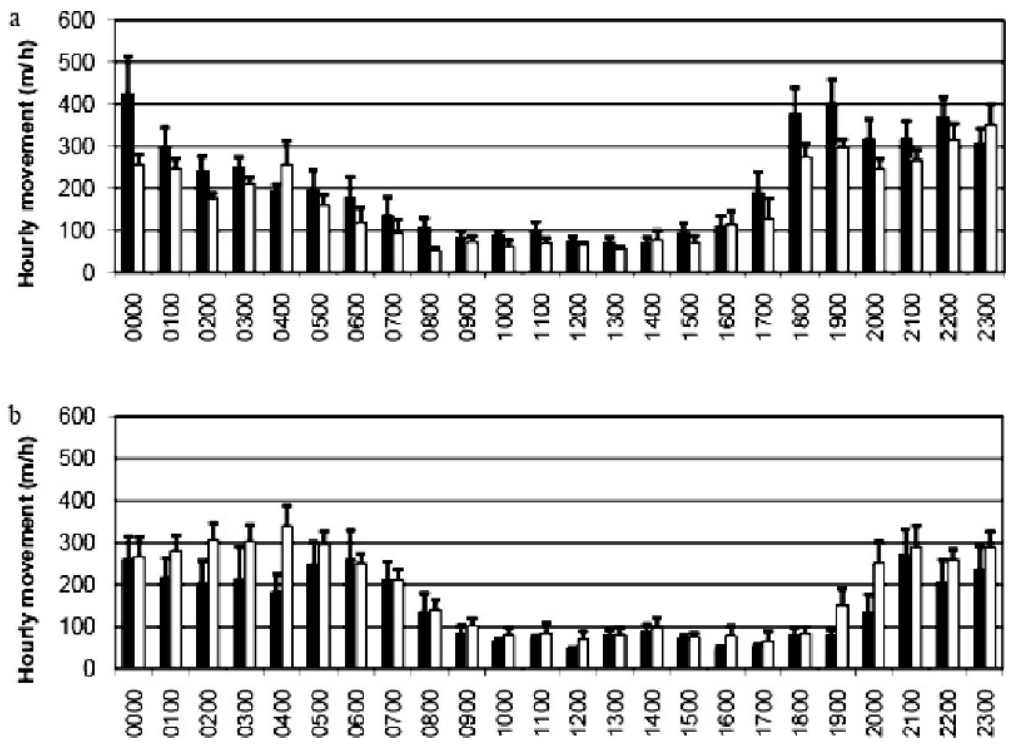

FIG. 2-Average $( \pm S E)$ hourly movement $(\mathrm{m} / \mathrm{h})$ of male (closed bars) and female (open bars) wild boars (Sus scrofa) in (a) Kleberg (January-March) and (b) San Patricio (May-July) counties, Texas, 2008.

Additionally, no pattern was evident relative to daily activity over time (Fig. 1). Hourly movements in both study sites suggested nocturnal activity (Fig. 2). Activity in Kleberg County increased with rising temperatures $(n=14, y=$ $\left.146.37+3.403 x, r^{2}=0.262, P=0.06\right)$. However, we did not observe this in San Patricio County, where we detected no relationship between activity and temperature $(n=15, y=-66.97+$ $\left.7.214 x, r^{2}=0.076, P=0.32\right)$.

With our $\leq 15$-week period of GPS monitoring on each study site, we detected no within-season trend in activity. Rates of movement were relatively constant throughout our assessment on each site. Our observations in Kleberg County that males generally moved greater distances per day than females indicated that males were more active than females, which is consistent with observations of wild boars in Australia (Saunders and Kay, 1991; Caley, 1997). However, our data from San Patricio County were surprising and suggested there was less activity by males than by females. In fact, mean daily movement of ca. $7 \mathrm{~km} /$ day for females during 15-16 July in San Patricio County was the greatest we observed at both sites and for both sexes. An explanation for this elevated activity by females in San Patricio County may involve differences in the reproductive cycle. For example, females in San Patricio County may have been raising young during our study; thereby, displaying greater activity than solitary males (Sweeney et al., 2003).

Using telemetry techniques, previous work in Tennessee (Singer et al., 1981) and Australia (Dexter, 1996; Caley, 1997) reported wild boars to be primarily nocturnal. Our data for hourly movements concur with these findings; overall, wild boars in southern Texas appear to be nocturnal. Additionally, our observations in Kleberg County validate a previous report of nocturnal activity determined from visitation to scent stations within the county (Campbell and Long, 2008). Furthermore, we did not observe shifts in periods of activity (Kurz and Marchinton, 1972). In Kleberg County, peaks in activity for males and females occurred during 0000 and 2300 h, respectively. In San Patricio County, peaks in activity for males and females occurred during 2100 and $0400 \mathrm{~h}$, respectively.

Our data related to temperature suggest that during the dormant and early growing season (January-March) wild boars increase activity during warmer periods. However, our data for summer (May-July) suggest no influence of temperature. This observation is counter to data (i.e., trapping success) reported from eastern and southern Texas (Wyckoff et al., 2006). We believe that reductions in trapping success were observed during summer because of availability of alternative forage associated with the growing season 
and, therefore, not directly related to temperature. In fact, during summer droughts, we believe that trapping success can be increased above other times of the year by targeting trapping effort near sources of water (Webb et al., 2006).

We thank T. Blankenship, J. Delgado-Acevedo, A. Foley, K. Kubala, and J. Moczygemba for assistance with collection of data. We are grateful to E. CardenasCanales for translating the abstract to Spanish. We appreciate logistical support provided by personnel of Welder Wildlife Foundation, King Ranch, Inc., and the Caesar Kleberg Wildlife Research Institute at Texas A\&M University-Kingsville.

\section{Literature Cited}

Boitani, L., L. Mattei, D. Nonis, and F. Corsi. 1994. Spatial and activity patterns of wild boars in Tuscany, Italy. Journal of Mammalogy 75:600-612.

Caley, P. 1997. Movements, activity patterns and habitat use of feral pigs (Sus scrofa) in tropical habitat. Wildlife Research 24:77-87.

Campbell, T. A., and D. B. Long. 2008. Mammalian visitation to candidate feral swine attractants. Journal of Wildlife Management 72:305-309.

Dexter, N. 1996. The effect of an intensive shooting exercise from a helicopter on the behaviour of surviving feral pigs. Wildlife Research 23:435-441.

Environmental Systems Research Institute. 1999. ARCVIEW. Version 3.2. Environmental Systems Research Institute, Redlands, California.
Ilse, L. M., And E. C. Hellgren. 1995. Resource partitioning in sympatric populations of collared peccaries and feral hogs in southern Texas. Journal of Mammalogy 76:784-799.

Kurz, J. C., And R. L. Marchinton. 1972. Radiotelemetry studies of feral hogs in South Carolina. Journal of Wildlife Management 36:1240-1248.

Saunders, G., and B. Kay. 1991. Movements of feral pigs (Sus scrofa) at Sunny Corner, New South Wales. Wildlife Research 18:49-61.

Singer, F. J., D. K. Otto, A. R. Tipton, and C. P. Hable. 1981. Home ranges, movements, and habitat use of European wild boar in Tennessee. Journal of Wildlife Management 45:343-353.

Sweeney, J. R., J. M. Sweeney, and S. W. Sweeney. 2003. Feral hog Sus scrofa. Pages 1164-1179 in Wild mammals of North America (F. A. Feldhamer, B. C. Thompson, and J. A. Chapman, editors). Second edition. Johns Hopkins University Press, Baltimore, Maryland.

Webb, S. L., C. J. Zabransky, R. S. Lyons, and D. G. Hewttt. 2006. Water quality and summer use of sources of water in Texas. Southwestern Naturalist 51:368-375.

Wilson, D. E., And D. M. Reeder. 2005. Mammal species of the world: a taxonomic and geographic reference. Third edition. Johns Hopkins University Press, Baltimore, Maryland.

Wyckoff, A. C., S. E. Henke, T. A. Campbell, and K. C. VerCauteren. 2006. Is trapping success of feral hogs dependent upon weather conditions? Proceedings of the Vertebrate Pest Conference 22:370-372.

Submitted 2 July 2009. Accepted 20 March 2010. Associate Editor was Troy A. Ladine. 